\title{
MAST CELL, THE PECULIAR MEMBER OF THE IMMUNE SYSTEM: A HOMEOSTATIC ASPECT
}

\author{
GYÖRGY CSABA* \\ Department of Genetics, Cell and Immunobiology, Semmelweis University, \\ Budapest, Hungary
}

(Received: 19 May 2015; accepted: 18 June 2015)

\begin{abstract}
The mast cell is a member of the immune system having a basic role in allergic (anaphylactic) reactions. However, it contains, synthesizes, stores and secretes lots of substances, which initiates other reactions or participates in them. These are in connection with the deterioration of tissue correlation, as malignant tumors, angiogenesis, wound healing, pregnancy and different pathological conditions. In addition - as other members of the immune system - mast cells can synthesize, store and secrete hormones characteristic to the endocrine glands and can transport them to the site of requirement (packed transport), or produce and employ them locally. The effect of mast cells is controversial and frequently dual, stimulatory or inhibitory to the same organ or process. This is likely due to the heterogeneity of the mast cells, in morphology and cell content alike and dependent on the actual condition of the targeted tissue. The cells are transported in an unmatured form by the blood circulation and are exposed to microenvironmental effects, which influence their maturation. Their enrichment around tumors suggested using them as targets for tumor therapy more than fifty years ago (by the author), however, this idea lives its renaissance now. The review discusses the facts and ideas critically.
\end{abstract}

Keywords: mast cells, pineal, regulation, homeostasis, therapy

\section{Introduction}

The mast cells had been recognized one and a half century ago by von Recklinghausen as granular cells in the mesentery of the frog, however later, in 1878 Paul Ehrlich, who stained them with aniline-dyes, gave the mast cell name, as these cells were filled with metachromatically stained granules. At present, still these stains are used for histological demonstration or the alcian blue-safranin method [1] which can give also information on the degree of maturation

\footnotetext{
*E-mail: csagyor@dgci.sote.hu
} 
[2-4]. The cells have a haemopoietic origin, as other members of the immune system however, the mast cells are transported in unmatured state to the mucosal or connective tissue places of different organs, where the process of maturation is taking place $[5,6]$.

The numerous substances settled in the granules and intergranularly were discovered gradually and at least the mast cells were classified as immune cells, a special member of the immune network. Today the cells are registered as a main factor of allergic reaction, having receptors and reacting to $\operatorname{IgE}$, synthesizing and secreting histamine. However, only a portion of biologically active molecules contained by them are used in allergic or anaphylactic reactions and the cells are enriched particularly in such locations which are in close contact with the external environment (skin, lung, intestines) [7] as well, as in the area of different pathophysiological processes. In addition, now the other - not directly immunological - functions of the whole immune system are in the front line of investigations [8]. This can explain why the others, non-immunological functions of mast cells are also studied lately.

\section{Mast cells and tumors}

Already at the end of the nineteenth century Paul Ehrlich, the "father of immunology" observed and described in his Doctor Theses [9], that mast cells are accumulated around and sometimes inside malignant tumors. Since this time this observation has been verified many times [10] and the role of tumor derived growth factors [11, 12], stem cell factor, tumor necrosis factor (TNF) and CXL12 [13], in the attraction of mast cells also has been cleared [14]. Mast cells arrive very early to the site of tumorous proliferation and stay there - regulating the growth process - up to the end-phase [12]. However, though more than a century passed, the exact role of mast cells seems not to be clear and it is multifaceted. There are some cases when mast cells stimulate [15], in other cases inhibit the growth of tumors $[14,16]$. This dual role can be explained to some extent by the huge number of materials contained (produced) and secreted by mast cells as well, as the differences between mast cells in morphology and function [10] and the differences between tumors.

\section{The tumor-influencing biologically active components of mast cells}

The granules of mast cells contain heparin, histamine and serotonin and various proteases. In addition other molecules are also present inside and extragranularly, as cytokines, leukotrienes, chemokines, prostaglandins and many 
growth factors $[16,17]$. Parts of the molecules are releasing during degranulation together, however, there is a possibility of secretion by individual granules without complete degranulation and also intra- or extragranular mediators selectively (peacemeal degranulation) [16-19]. It is believed that for the tumor promoting effects the secretion of molecules is needed without degranulation [16].

While heparan sulphate which has a polysaccharide backbone identical to heparin is present in practically all cells of mammals, heparin is synthesized solely in mast cells [20]. In the medical practice heparin is an anticoagulant. However, during degranulation of mast cells it enriches around the cells influencing the microenvironment as well, as the coagulation ability of the blood. Heparin (or heparan sulphate) influences cell division, influencing the number and velocity of mitoses as well, as the appearance of atypical forms [21, 22]. It inhibits histamine release from mast cells [23], stimulates migration of capillary endothelial cells [24, 25] and proliferation of intestinal epithelial cells [26]. It also influences the angiogenesis and the immune system [27, 28]. It is needed for the storage of histamine and proteases in the mast cell granules [29].

It was demonstrated in some studies that heparin either inhibits [17] or enhances $(15,30)$ the tumorous proliferation [28]. In this latter case it assists in promoting blood-borne metastasis [31, 32], which is inhibited by anticoagulants [33]. It is justified that the components of heparin, glucuronic acid and glucosamine stimulate the growth of tumors $[34,35]$ and shorten the lifespan of the animals, without acting to the non-tumorous controls. The extreme accumulation of mast cells around the tumors sometimes means a poor prognosis $[15,17]$. This was expressed in the negativity of the diagnostic agar binding reaction at the end stage of tumor bearing patients [36-39], caused by the extreme degranulation of mast cells and consequently the enrichment of heparin in blood. However, in other experiments the higher number of mast cells around the tumor was a favorable prognostic factor [40, 41].

The other main component of the granule, histamine is known at first in connection with allergic and inflammatory reactions. However, based on many data, it has important positive or negative influence to mitosis of healthy cells [42-45] depending on the cell type and experimental conditions. Histamine is present and secreted by each mast cell-type $\left(\mathrm{MC}_{\mathrm{TC}}, \mathrm{MC}_{\mathrm{T}}\right.$ and $\left.\mathrm{MC}_{\mathrm{C}}\right)$. Data show that histamine, and the other components, serotonin and heparin are packed in the same granules [46]. However, there are two types of serotonin storage proteins, one is membrane associated, the other is free [47]. Histamine can influence the behavior of tumors. This role is also dual, as tumor cells have H1, H2 and H4 receptors and histamine enhances tumor growth acting to the $\mathrm{H} 1$ receptors and suppresses it through $\mathrm{H} 2$ and H4 [16]. In addition, histamine has a local immunosuppressive effect [48]. Studying hepatoma cell lines, in HuH-6 cell viability and 
proliferation were hampered by it, while in HA22T/VGH cell proliferation increased [49]. When lung cancer has been induced, histamine inhibited this, while it was tumorogenic in case of lung tumor cell lines [50]. In case of melanoma, histamine can effect positively or negatively, depending on its local concentration and the type of receptors present [51-53]. In case of colon cancer cells enhancement of growth and proangiogenic effect was observed through $\mathrm{H} 2$ and $\mathrm{H} 4$ receptors and cyclooxygenase (COX-2) was involved in the process $[49,54]$. When protumorigenic effect is manifested (caused by the collaboration of histamine and heparin), this favors the formation of metastases $[12,55]$.

In addition to heparin and histamine, acid hydrolases are present in the mast cell granules which are secreted by or without degranulation. These are chymase, tryptase, beta-hexosaminidase beta-glucuronidase, beta-D-galatosidase, and aryl sulphatase, ionically bound to heparin [56]. The heparin protein complex is bound to histamine [57]. Because of the presence of acid hydrolases, the granule is believed to be a modified lysosome. In rodents the mucosal type mast cell can be differentiated histochemically (morphologically) from connective tissue mast cells. In human beings the basis of differentiation is the chymase or tryptase content [58]. Although about $50 \%$ of the total protein content in mast cells is the mass of proteases, their function is dubious in general and unknown in case of tumors [59, 60]. However, the flood of hydrolases is poured in a fully active form during degranulation and this must effect the microenvironment. Tryptase is not only a proteinase, but a specific growth factor for fibroblasts [61]. In addition metalloproteases are also present in mast cells and their secretion helps tumor cell proliferation, migration and metastasis formation, by the destruction of the tumor-controlling environment [62]. Tumor cells also have a collagenolytic activity, which is stimulated by mast cells [63].

Cytokines and growth factors are also synthesized by mast cells, which has positive or negative effects on the tumorous proliferation depending on the state of tumor. The cytokines which have antitumor activity are IL-1, IL-2, IL-4, IL-6, IL-10 and IFN-gamma, while the tumor promoting growth factors are TNF-alpha, TGF-beta 1, FGF-2, VEGF, PDGF, IL-8, NGF and osteopontin [6466]. The mast cells also have membrane receptors for numerous cytokines and chemokines which help or inhibit the accumulation of cells [67].

Chemokines are also cytokines, with cell migration and attraction influencing effects. Mast cells are producing chemokines, as IL-8, CXCL1/GRO alpha, CXCL8, CXCL10/IP10, MCP-1 and RANTES [68-70]. They also have receptors for chemokines [71]. As tumors also secrete chemokines, their secretion attracts mast cells which accumulate in the environment of tumors. 
The tumor cells can proliferate at first without vascularization, however, after exceeding $5 \mathrm{~mm}$ they require the ingrowth of vessels. This process is stimulated or inhibited by substances secreted by the mast cells [72], which are the earliest cells infiltrating the developing tumor [73]. The stimulators (pro angiogenic factors) are the growth factors, CSF, NGF, PDGF, SCF, VEGF, IL-8, bFGF, TGF-beta, VPF, osteopontin, angiogenin and histamine [74-76], the inhibitor is protamin [77, 78]. Heparin has a dual role: in some cases it has stimulatory, in other cases inhibitory effects [24, 78-81]. The experimental results are sometimes contradictory, for example VEGF is one of the most potent angiogenic growth factor $[31,82]$, however, in lung cancer the number of mast cells correlate in the grade of angiogenesis independently of VEGF expression [81]. All of the anti-angiogenic factors act through the inhibition of mast cell products [83]. When mast cells influence tumor angiogenesis, remodelling blood vessels [84], it also determines the further fate of the tumor, helping or suppressing the migration of the tumor cells and by this, metastasis formation [85].

\section{Mast cells and wound healing}

Mast cells have an important role in wound healing [86], secreting growth factors and histamine alike [87]. However, excess or deficit of mediators released could cause abnormal repair (of skin), with keloid or hypertrophic scar formation [88]. The results are contradictory, as some experiments demonstrate that mast cells are needed for wound tissue granulation, blood wessel formation and collagen maturation $[89,90]$, while other experiments show that mast cells do not exert major influence to the proliferation of cells during healing [91]. In fetal life mast cells positively influence the scarless repair [92]. An increased number of mast cells can be found in fibrotic diseases - in contrast to normal healing around blood vessels [93]. Mast cells have a role in remodelling the tissues: cell breakdown, repair and regeneration [94, 95]. In this process IL-33, released by the necrotic cells and recognized by the receptors of mast cells, has an important role [96]. Mast cell proteases have a role in tissue repair, promoting healing however, and mast cell overweight could be detrimental [97]. 


\section{Endocrine function of mast cells}

\section{Hormones produced and secreted by mast cells}

In addition to the main granule components, the biogenic amine histamine and serotonin (which also have hormonal function), other signal molecules are present in mast cells. These are the hormones produced mainly by endocrine glands, however, mast cells - similarly to other immune cells - can produce, store and secrete them $[8,98]$. Triioidothyronine (T3), adrenocorticotropic hormone $(\mathrm{ACTH})$, chorionic gonadotropin (hCG), vascular endothelial growth factor (VEGF) [99] and endorphin were demonstrated immunohistochemically in rat mast cells [100-103]. At the same time the demonstration of insulin and epidermal growth factor was unsuccessful. The amount of the hormones was genderdependent, in most of cases higher in females [101]. Corticotropin releasing hormone $(\mathrm{CRH})$ and its relative, urocortin were also found in human mast cells [104]. The atrial natriuretic peptide (ANP) is produced, stored and secreted during degranulation by rat peritoneal mast cells [105] and prostaglandins were also found [106-107]. A rat mast cell line synthesizes and releases melatonin [108]. Histamin and serotonin can be demonstrated not only in the granules, but also in the nucleus of mast cells as well, as ACTH and growth hormone [100, 109].

For the synthesis of histamine, histidine as basic molecule is needed. For the maturation of granule also histamine synthesis is required, this means that the action of Hdc gene must be present for granule maturation [110]. Hdc-knockout mice have less mast cells and altered morphology of mast cell granules [111]. This seems to be clear. However, in these animals the production of ACTH, T3 and endorphin is also touched [112]. A similar role of mast cell histamine was observed in the case of parathyroid gland [113].

The hormone production, storage and secretion can be influenced by hormonal imprinting, when the effect of neonatal treatment with the hormone is manifested later in adults, changing the endocrine function of the mast cells [114]. Neonatal imprinting with a single dose of endorphin significantly diminished the endorphin, serotonin and hCG content of adult's mast cells [102] and imprinting at weaning also decreased the endorphin and serotonin content in adults [115].

\section{Hormone receptors and hormonal regulation of mast cells}

Not only hormones, but hormone receptors are present in mast cells. Using the transmission by these receptors, the hormone production, storage and secre- 
tion of mast cell hormones can be regulated. Thyrotropic hormone (TSH) influences T3 concentration of mast cells similarly to the regulation of the same process in the thyroid gland [116]. This can be explained by the presence of T3 receptors in the cytoplasm and nucleus of mast cells [117]. In the thyroid gland the exocytosis (degranulation) of mast cells is synchronized with thyroid activity [118].

MT1 and MT2 melatonin receptors are also present in the plasma membrane of mast cells [108]. By the transmission of them, the pineal gland can influence the development and function of mast cells [119-121]. Mast cells can influence the calcification of the pineal gland [122].

The cells do not contain glucocorticoids, however, these hormones have inhibitory effects on degranulation and other forms of secretion [123], while suppress mast cell survival $[123,124]$, reduce mast cell number in diabetic rats [125] and influence mast cell development [126]. Exogeneously given corticosterone is able to build into the components of mast cells [127,128]. The cells have estrogen, androgen and progesterone receptors alike [129-131] and the hormones, by the transmission of these receptors influence the maturation of mast cells and secretion of the molecules [126, 132-134]. They also react to the hormones of the pineal-thyroid-thymus system $[135,136]$. Corticotropin releasing hormone (CRH) receptors are also present and VEGF secretion is promoted by $\mathrm{CRH}$ in mast cells [137]. In the ovarian complex 17-beta estradiol was the strongest degranulator of mast cells, however, luteinizing hormone $(\mathrm{LH})$, follicle stimulating hormone (FSH) and TSH also showed this effect [138]. ACTH is a strong degranulator, too $[139,140]$.

The hormone of the parathyroid gland, parathormone (PTH) in vitro and in vivo stimulates mast cell degranulation [141]. It seems likely that the cells have a role in bone turnover and the increased number of mast cells is in connection with accelerated bone loss and the deficiency with stimulated osteoblastic function [142]. PTH excess causes the increase of mast cells at the bone-bone marrow interface in case of elevated PTH level (hyperparathyreosis) [143].

Insulin influences (inhibits) mast cell degranulation and histamine release during diabetes [144] and it is hypothesized that mast cells are involved in insulin resistance and type 2 diabetes [145].

Stress is a general activator of the endocrine system and has a dual role to the immune system. By this, it activates the CRH-mast cell-histamine axis [146]. A perinatal stress - causing hormonal imprinting - durably elevates the ACTH level in mast cells of adult male rats [147]. 


\section{The sentinel function of mast cells}

Mast cells have a sentinel function in innate and adaptive immunity, however they have similar role in pregnacy and pathophysiological conditions [148]. As the earliest defense cell, which contains and secretes a mass of biologically active materials during tumor formation or pregnacy, it also has a sentinel function [72]. Located under the epithelial surfaces, it is a sentinel in the case of bacterial or parasitic infections as well, as sensing cell injury [96, 149].

\section{Mast cells and pregnancy}

A huge amount of mast cells are present in the uterus and the placenta. It was measured that the placenta contains $7.6 \times 10^{5}$ mast cells $/ g$ wet weight tissue [150] and these cells release histamine during degranulation. During pregnancy mast cell density is higher than in non-pregnant state [151]. The histamine (and serotonin) liberated from the uterine mast cells control cervical function [152] and influences the conractility of myometrium [153]. This latter is supported by in vitro experiments, when myometrial strips were studied [154]. It is suggested that mast cell histamine is important in normal ovulation and blastocyst implantation [155], acting through histamine H1 receptors [156]. Mast cells also influence early abortions, justified by the enormous increase of mast cells of decidua (from 36.27 to $448.7 / \mathrm{mm}^{2}$ ) in this case [157]. It seems likely that this effect is controlled by secretion of cytokines. The mast cells could have a dual role in the reproductive system, as the early $[157,158]$ stage of pregnancy helps blastocyst implantation and blood flow regulation [155], however, later they can activate preterm delivery [159]. Their angiogenic effect is also important in case of the cervix [160].

\section{Metabolic syndrome and other - non-immune - diseases}

Mast cells have a significant role in such metabolic syndromes as obesity and type 2 diabetes, as well as in insulin resistance [144, 145]. The white adipose tissue contains a large amount of mast cell precursor hemopoietic cells [161], in physiological and pathological conditions alike. The prostaglandins produced and secreted by mast cells induce adipocyte differentiation and can cause obesity [106]. The preadipocyte-adipocyte transformation is helped by mast cells [162]. In leptin-deficiency induced obesity the epididymal fat showed a 20 -fold increase and a 13-fold decrease of subcutaneous fat mast cell number and also a mast cell 
increase in the lymph nodes [163]. Mast cell proteases, chymase and tryptase are risk factors for diabetes and the stabilization of mast cells decreases the chance to diabetes [164]. Mast cell function inhibitors can be a promising treatment of obesity in the future [165].

Cardiovascular diseases are or can be promoted by mast cells [166, 167]. The mast cell-specific proteases have a role (in animal experiments) in the development of atherosclerosis and aneurisms [168] and selective chymase and tryptase inhibitors have beneficial effects in these cases. Mast cell stabilizers (anti-allergy medications) also decrease cardiovascular complications [169]. Not only the proteinases have a role in the formation of atherosis plaques, but some growth factors, histamine and chemokines [170]. Alzheimer disease is among the pathological states which are also influenced by mast cells [107, 171]. It is supposed that the protease of them generates the production of perivascular beta protein which aggregates into beta-amyloid deposits. In the gastrointestinal (GI) area mast cells are involved in increased gastric secretion, polyp formation and irritable bowel syndrome [172]. It seems to be likely that the central nervous system influences GI mast cells and vica versa [173, 174].

\section{Conclusions}

The immune system contains different cells which can differentiate between self and non-self and after recognition it destroyes the non-self, either this penetrates into the organism from outside (bacteria, viruses and parasites) or develops inside it. However, the cells of the immune system (lymphocytes, monocyte-macrophage cells and mast cells) synthesize, store and secrete hormones, characteristic to the endocrine glands. Nevertheless, the cells of the endocrine glands are monoproducers, synthesizing one hormone, while the cells of the immune system are polyproducers, synthesizing almost all amino-acid or polypeptide hormones, which were searched at all. The mast cell is an outstanding member of this immunoendocrine system, as rich in hormones and hormone-like molecules (e.g. growth hormones, osteopontin, etc.) and in addition it also synthesizes and secretes other biologically active and important substances, as heparin and proteolytic enzymes (chymase, tryptase), which are bound to each other in the granules and can be secreted together, or separately. This factory of biologically active molecules is mobile and can transport the molecules ready for secretion to different places of the organism, where there is a requirement to them (packed transport) $[8,175]$. The requirement is sensed by receptors present in the plasma membrane of mast cells, which are in a close contact with blood vessels. It seems likely that this is the reason why mast cells are among the first cells, 
which reach the developing tumors. The ability of packed transport (of hormones) is also a property of all immune cells, however, the mast cell is the largest factory, which transports the most molecules and which can fabricate the most active molecules locally. Although it was not tested that the locally secreted hormones influence the proliferation of tumors or not, this is theoretically not precluded. T3 e.g. can influence cell proliferation $[176,177]$ and it is synthesized and secreted by mast cells.

At the lowest level of eukaryotic phylogeny the unicellular eukaryotes, as Tetrahymena, synthesize hormones, characteristic to mammals and able to communicate by the help of them [178, 179]. The cell is a polyproducer and also polyreceiver, having receptors for the hormones, which are strenghtened after imprinting [180]. While the primitive cells which accumulate to form the endocrine glands during the evolution, loose this multifaceted capacity, the immune cells (up to the mammals) keep this property, and first of all the mast cells [181], which produce the flood of signal molecules and express a huge number of receptors, as it is in Tetrahymena [178]. These cells are very ancient, their ancestors can be found in Ciona intestinalis or Styela plicata, the origin of which can be deduced to at least 500 million years ago $[182,183]$.

Although mast cell is a member of the immun system, its functions are different from the other members. It does not participate directly in the recognition of non-self and does not destroy it, as it is done by lymphocytes and macrophages. As an immune cell, it is participating first of all in the allergic reactions, however, it sustains the tissue homeostasis, the healing processes after injury and helps in the remodelling of the destroyed tissue patterns. Considering that in our most present knowledge the immune system in general serves not only the recognition and destruction of non-self, the prominent homeostatical role of mast cells is not surprising. However, if the first recognized function of mast cell would have been this homeostatic one, it would be recorded as a special homeostasis controlling cell, which has also immune function, as one of its numerous properties.

Another speciality of mast cells is the presence of hormones in the nucleus. However, not all of the hormones produced by the mast cells themselves can be found, but histamine and serotonin, the main components of granules and ACTH as well, as growth hormone, are present, while T3, insulin and endorphin were not found. Other immune cell nucleus did not show this phenomenon, in these cells at most around the nucleus were hormones found [184]. It is not known whether the intranuclear hormones are the self-products of mast cells or they were taken up from the bood circulation. However, cytoplasmic or intranuclear receptors for these hormones are unknown. Also unknown is the function of the hormones in the nucleus. 
As it was told, the mast cells have a bone marrow origin [185], however, their maturation takes place in different lymphoid organs (at first in the thymus) $[186,187]$ as well, as in different places of the organism, to where they are transported by the blood circulation $[188,189]$, which is not a passive transporter, as the serum helps the maturation of the cells [190]. The microenvironment also has a determining effect to them. KIT ligand, acting on the KIT receptor is the most important factor in the development of the cell [185], however, it seems likely that the environment evokes different types of mast cells, which is manifested e.g. in the chymase or tryptase overweight and in the different staining of the connective tissue mast cells (CTMC) and peritoneal mast cells [191]. CTMCs keep their proliferation potential after maturation, while mucosal mast cells lose it [185]. CTMCs and mucosal mast cells are located in different places, after transplanted together. However, in case of peritoneal mast cells, the large granule-stuffed cells are inactive, while the small (young) and medium-sized cells are active and can contact other cells (e.g. lymphocytes), which influences their behavior [192]. There are also differences in the receptivity and answer to hormones depending on the location, maturity and type of mast cells [137-139]. Considering the heterogeneity of the mast cell population [193, 194], it is very difficult to develop an uniform opinion about the functions of mast cells, without mentioning their type or localization. However, as the mast cells are mainly characterized by the metachromatic staining of granules, theoretically also imaginable that the different members of the population in an organism are different cell types (containing heparin) with different functions. Due to it, the dual roles, which are present frequently in connection of mast cell functions, can be explained.

As it was clearly seen that mast cells produce numerous substances, the question is, what is the primary, which induces the synthesis of others, or what is the organizer of granule formation. In experimental conditions histamine or serotonin induces heparin formation, whilst heparin is not able to induce the formation of them [195]. Also, in cell-free model granule formation only takes place, if all components are present in a suitable ratio [196]. In vivo histamine synthesis is needed for the granule formation [110]. This means that histamin is the primary, which initiates heparin synthesis. In addition, as histamine can be released from the granule without degranulation something is needed to bind the heparin after that. This "something" is histone [197, 198], which also present in the granule and being a basic protein, can bind the acidic heparin. These scarce data show that there is a self-regulation inside the cell, in addition to the regulating function of microenvironment.

There is always a problem, whether the above listed properties are the specificities of mast cells, or other cells also have them, however, they were studied less, while mast cells were in the front of interest. When the hormones were 
studied in the immune cells, practically all of them were found (except steroids) and from this point of view there was no difference among the different cells. There is a possibility that other members of the immune system contain the majority of materials found in mast cells, however, this was not studied or the results were not published. So, it must be cautious to declare their speciality in all of the functions or contents, however, some materials are characteristic to them. These are heparin (the molecule by which it can be found histochemically), histamine, and the protease enzymes. Considering the heterogeneity of the cells, we call mast cells all of the cells, which contain these components, and in the cytoplasm have metachromatically stained granular structures.

Most of the biologically active components of the mast cells are peptides and amino acid-like materials except heparin, which is a stranger, a polysaccharide. It is composed of glucosamine and glucuronic acid. It is not known whether these two components of heparin are synthesized by the cell itself or are taken up from the milieu [199]. However, the tumor growth promoting effect of these molecules has been demonstrated $[10,34]$. When the development of a malignant tumor started, mast cells accumulated around it, attracted by the factors secreted by the tumorous cells. It is likely that not specifically the tumor attracts the mast cells, but the breaking down of tissue correlation (harmony), as the mast cells are accumulating also in other places, where the tissue correlation is destroyed [200], e.g. in wound healing or pregnancy. The surrounding mast cells have a dual role on the development of the tumor, promoting or inhibiting it. Considering the huge number of materials present in mast cells, this controversial effect can be done by different substances secreted, or the same substance secreted in different periods of tumor development. If mast cells in the neighborhood of the tumor take up heparin or its components, concurring with the tumor, which also require them for the proliferation, this causes inhibition. In opposite, the degranulation of mast cells presents heparinoids for use.

It is an interesting question, why tumors secrete such substances, which attract mast cells, if these cells can be harmful to the organism, stimulating the growth and development of the tumor. One of the explanations could be that the malignant tumor is autonomous and by this activity it helps the propagation of malignancy. Another - and most likely - explanation is, that the accumulation of mast cells is provoked by the disturbance of local homeostasis, independent on its malignancy or benevolency. They "want" to restore the normal state, while such substances are also released which promote the tumorous proliferation. The situation is similar to the spontaneous action of immune cells, which offend the useful transplanted tissue because of its nonselfness.

It is not dubious that mast cells have negative or positive influence on tumor development, however, there are no data on their effect on tumor formation. The 
suppression of immunity promotes tumor formation, nevertheless, the role of mast cells in the process is unknown. Considering the role of mast cells in the restoration of tissue homeostasis, the effect of their blockade (e.g by psychosocial depression) to this process can be suspected, however, it was not studied.

More attention would be needed for the dual role also in other cases. Not only the tumorous proliferation destroyes the normal local homeostasis, but pregnancy too. It seems likely that this attracts a huge number of mast cells there. Considering the importance of this physiological process, relatively scarce data are at our disposal on the role of mast cells in the maintenance or rejection of the half-strange embryo. However, the present data point to this problem and call attention to the possibility of prevention or treatment by influencing the behavior of mast cells.

At present, authors of numerous papers propose an attack against tumors by targeting the mast cells around or inside it [14, 41, 201-203]. It is mentioned as a new field of treatment. However, this kind of therapy was proposed more than 50 years ago and there were experiments which supported this possibility. The author of this paper proposed 1) the binding of cytostatics to a heparinoid transporter which could help the accumulation of it around tumors, or 2) the binding of cytostatics to metachromatic dyes. Both methods were executed in animal experiments and resulted in very effective tumor destruction and life prolongation of tumor bearing animals [204-209]. Some of them were studied on human beings, with positive results [210]. In that time less was known on the role of mast cells in general. However, this line of tumor treatment or similar ones can be continued.

When I am writing this review paper, PubMed lists about 37,000, and Google shows 182,000 papers in which "mast cell" is found. This review contains 210 citations. It was very difficult to select those papers which really represent the important functions of mast cells, or show exactly what diseases in which mast cells have decisive non-immune roles. There could be functions which are more important, than those of presently known, however, they were not studied in the absence of intention, or tools for doing it. Nevertheless, the paper shows what the main non-immune functions are of mast cells at present, and what the directions of research are. It also points to some almost forgotten data and ideas, which seem to be timely.

Considering the above mentioned facts and ideas, it can be accepted that mast cells are members of the immune system with strong heterogeneity and other - non-immune - functions. These functions seem to be as important, as the immune one. Although almost month after month new functions are recognized, sometimes the old functions are still uncertain and frequently controversial, except their key role in allergy and anaphylaxis. As the study of non-immune func- 
tions of mast cells is in progress, also the therapeutic application of the new knowledge is hopeful.

\section{References}

1. Spicer, S. S.: A correlative study of the histochemical properties of rodent acid mucopolysaccharides. J Histochem Cytochem 8, 18-35 (1960).

2. Csaba, G., Oláh, I.: Mechanism of the formation of mast cell granules, 8. Ultrastructure of model granules. Acta Biol Acad Sci Hung 23, 133-144 (1972).

3. Csaba, G., Forgács, A.: The ontogenesis of mast cells. Acta Biol Acad Sci Hung 22, 423-430 (1971).

4. Csaba, G., Oláh, I.: Mechanism of the formation of mast cell granules I. Ultrastructural and histochemical study in a model consisting of living cells. Acta Biol Acad Sci Hung 19, 347-362 (1968).

5. Yong, L. C.: The mast cell: Origin, morphology, distribution, and function. Exp Toxicol Pathol 49, 409-424 (1997).

6. Moon, T. C., St. Laurent, C. D., Morris, K. E., Marcet, C., Yoshimura, T., Sekar, Y., Befus, A. D.: Advances in mast cell biology: New understanding of heterogeneity and function. Mucosal Immunology 3, 111-124 (2010).

7. Zhang, J., Shi, G. P.: Mast cells and metabolic syndrome. Biochem Biophys Acta 1822, 14-20 (2012).

8. Csaba, G.: The immuno-endocrine system: Hormones, receptors and endocrine function of immune cells. The packed transport theory. Adv Neuroimm Biol 1, 71-85 (2011).

9. Ehrlich, P.: Beitrage zur Theorie und Praxis der Histologischen Farbung. Thesis, Leipzig University, 1878.

10. Csaba, G., Ács, T., Horváth, C., Mold, K.: Genesis and function of mast cells. Mast cell and plasmacyte reaction to induced, homologous and heterologous tumours. Br J Cancer 15, 327-335 (1961).

11. Brzezinska-Blaszczyk, E., Pitrzak, A., Misiak-Tloczek, A. H.: Tumor necrosis factor (TNF) is a potent rat mast cell chemoattractant. J Interferon Cytokine Res 27, 911-919 (2007).

12. Conti, P., Castellani, M. L., Kempuraj, D., Salini, V., Vecchiet, J., Teté, S., Mastrangelo, F., Perrella, A., DeLutiis, M. A., Tagen, M., Theoharides, T. C.: Role of mast cells in tumor growth. Ann Clin Lab Sci 37, 315-322 (2007).

13. Polajeva, J., Sjösten, A. M., Lager, N., Kastemar, M., Waem, I., Alafuzoff, I., Smits, A., Westermark, B., Pejler, G., Uhrbom, L., Tschogounova, E.: Mast cell accumulation in glioblastoma with a potential role for stem cell factor and chemokine CXCL 12. Plos One 6, e25222 (2011).

14. Groot Kormelink, T., Abudukelimu, A., Redegeld, F. A.: Mast cells as target in cancer therapy. Curr Pharm Des 15, 1868-1878 (2009).

15. Tóth-Jakatics, R., Jimi, S., Takebayashi, S., Kawamoto, N.: Cutaneous malignant melanoma: Correlation between neovascularisation and peritumoral accumulation of mast cells overexpressing vascular endothelial growth factors. Hum Pathol 31, 955-960 (2000). 
16. Theoharides, T. C., Alysandratos, K. D., Angelidou, A. A., Zhang, B.: Mast cells and tumor microenvironment. In Bagley R. G.: The Tumor Microenvironment, Cancer Drug Discovery and Development. Springer Science and Business Media, 2010, pp. 353-375.

17. Theoharides, T. C., Conti, P.: Mast cells: The Jekyll and Hyde of tumor growth. Trends Immunol 5, 235-242 (2004).

18. Dabbous, M. K., Walker, R., Haney, L., Carter, M. L., Nicolson, G. L., Woolley, D. E.: Mast cell and matrix degradation at sites of tumour invasion in rat mammary gland adenocarcinoma. Br J Cancer 54, 459-465 (1986).

19. Theoharides, T. C., Bondy, P. K., Tsakalos, N. D., Askenase, P. W.: Differential release of serotonin and histamine from mast cells. Nature 297, 229-231 (1982).

20. Carlsson, P., Kjellén, L.: Heparin biosynthesis. Handb Exp Pharmacol 207, $23-41$ (2012).

21. Csaba, G., Kapa, E., Mold, K., Törö, I.: On atypical mitoses in tissue culture after heparin therapy. Z Mikr Anat Forsch 67, 131-139 (1961).

22. Fedarko, N. S., Ishihara, M., Conrad, H. E.: Control of cell division in hepatoma cells by exogenous heparin sulphate proteoglycan. J Cell Physiol 139, 287-294 (1989).

23. Inase, N., Schreck, R. E., Lazarus, S. C.: Heparin inhibits histamine release from canine mast cells. Am J Physiol 264, L387-L390 (1993).

24. Azizkhan, R. G., Azizkhan, J. C., Zetter, B. R., Folkman, J.: Mast cell heparin stimulates migration of capillary endothelial cells in vitro. J Exp Med 152, 931-944 (1980).

25. Mitsi, M., Forsten-Williams, K., Gopalakrishnan, M., Nugent, M. A.: A catalytic role of heparin within the extracellular matrix. J Biol Chem 283, 34796-34807 (2008).

26. Flint, N., Cove, F. L., Evans, G. S.: Heparin stimulates the proliferation of intestinal epithelial cells in primary culture. J Cell Sci 107, 401-411 (1994).

27. Tyrrell, J. D., Horne, A. P., Holme, K. R., Preuss, J. M., Page, C. P.: Heparin in inflammation: potential therapeutic applications beyond anticoagulation. Adv Pharmacol 46, 151-208 (1999).

28. Smorenburg, S. M., Van Noorden, C. J. F.: The complex effects of heparins on cancer progression and metastasis in experimental studies. Pharmacol Rev 53, 93-105 (2001).

29. Humphries, D. E., Wong, G. W., Friend, D. S., Gurish, M. F., Qiu, W. T., Huang, C., Sharpe, A. H., Stevens, R. L.: Heparin is essential for the storage of specific granule proteases in mast cells. Nature 400, 769-772 (1999).

30. Roche, W. R.: Mast cells and tumors. The specific enhancement of tumor proliferation in vitro. Am J Pathol 119, 57-64 (1985).

31. Ch'ng, S., Wallis, R. A., Yuan, L., Davis, P. F., Tan, S. T.: Mast cells and cutaneous malignancies. Mod Pathol 19, 149-159 (2006).

32. Kozlowski, E. O., Pavao, M. S.: Effect of sulfated glycosaminoglycans on tumor invasion and metastasis. Front Biosci 3, 1541-1551 (2011).

33. Bobek, V., Kovarik, J.: Antitumor and antimetastatic effect of warfarin and heparins. Biomed Pharmacother 58, 213-219 (2004).

34. Csaba, G., Horváth, C., Ács, T.: Some new data concerning the biology of tumors. The effects of heparin and its components on tumour growth. Br J Cancer 14, 362-366 (1960).

35. Dimitriadou, V., Koutsilieris, M.: Mast cell-tumor cell interactions: For or against tumour growth and metastasis? Anticancer Res 17, 1541-1549 (1997).

36. Csaba, G., Törő, I.: A new procedure for cancer diagnosis: The agar binding reaction. Z Krebsforsch 62, 481-494 (1958). 
37. Csaba, G., Törö, I.: On the exact mechanism of the agar-binding reaction in a quantitative method. Neoplasma 6, 366-382 (1959).

38. Káplár, Z., Kónya, Z., Szinnyai, M.: Use of Csaba-Törö's agar fixation reaction in the diagnosis of gynecological cancer. Orv Hetil 100, 1771-1773 (1959).

39. Kleine, N., Obrecht, P., Brahms, A.: Research on the agar binding reaction of Csaba and Törö. Klin Wochenschr 40, 201-205 (1962).

40. della Rovere, F., Granata, A., Familiari, D., D’Arrigo, G., Mondello, B., Basile, G.: Mast cells in invasive ductal breast cancer: Different behavior in high and minimum hormone-receptive cancers. Anticancer Res 27, 2465-2471 (2007).

41. Oldford, S. A., Marshall, J. S.: Mast cells as targets for immunotherapy of solid tumors. Mol Immunol 63, 113-124 (2015).

42. Harper, R. A., Flaxman, B. A.: Effect of pharmacologic agents on human keratinocyte mitosis in vitro. III. Inhibition by histamine and methylated analogs. J Invest Dermatol 65, 400-403 (1975).

43. Tutton, P. J.: The influence of histamine on epithelial cell proliferation in the jejunum of the rat. Clin Exp Pharmacol Physiol 3, 369-373 (1976).

44. Franzén, L.: Further studies on the relationship between drug-induced mast-cell secretion and local cell proliferation. Acta Pathol Microbiol Scand A 89, 57-62 (1981).

45. Norrby, K.: Intradermal mast-cell secretion causing cutaneous mitogenesis. Virechows Arch B 42, 263-269 (1983).

46. Wingren, U., Wasteson, A., Enerback, L.: Storage and turnover of histamine, 5-hydroxytriptamine and heparin in rat peritoneal mast cells in vivo. Int Arch Allergy Appl Immunol 70, 193-199 (1983).

47. Tamir, H., Theoharides, T. C., Gershon, M. D., Askenase, P. W.: Serotonin storage pools in basophil leukemia mast cells: Characterization of two types of serotonin binding protein and radioautograhic analysis of the intracellular distribution of $[3 \mathrm{H}]$ serotonin. J Cell Biol 93, 638-647 (1982).

48. Reynolds, J. R., Akhter, J. A., Magarey, C. J., Schwartz, P. J., Adams, W. J., Morris, D. L.: Histamine in human breast cancer. Br J Surg 85, 538-541 (1998).

49. Lampiasi, N., Azzolina, A., Montalto, G., Cervello, M.: Histamine and spontaneously released mast cell granules affect cell growth of human hepatocellular carcinoma cells. Exp Mol Med 39, 284-294 (2007).

50. Stoyanov, E., Uddin, M., Mankuta, D., Dubinett, S. M., Levi-Schaffer, F.: Mast cells and histamine enhance the proliferation of non-small cell lung cancer cells. Lung Cancer 75, 38-44 (2012).

51. Lázár-Molnár, E., Hegyesi, H., Pállinger, É., Kovács, P., Tóth, S., Fitzsimons, C., Cricco, G., Martin, G., Bergoc, R., Darvas, Z., Rivera, E. S., Falus, A.: Inhibition of human primary melanoma cell proliferaton by histamine is enhanced by interleukin-6. Exp J Clin Invest 32, 743-749 (2002).

52. Falus, A., Hegyesi, H., Lázár-Molnár, E., Pós, Z., László, V., Darvas, Z.: Paracrine and autocrine interactions in melanoma: Histamine is a relevant player in local regulation. Trends Immunol 22, 648-652 (2001).

53. Medina, V. A., Massari, N. A., Cricco, G. P., Martin, G. A., Bergoc, R. M., Rivera, E. S.: Involvement of hydrogen peroxide in histamine-induced modulation of WM35 human malignant melanoma cell proliferation. Free Radic Biol Med 46, 1510-1515 (2009).

54. Chianchi, F., Cortesini, C., Schiavone, N., Perna, F., Magnelli, L., Fanti, E., Bani, D., Messerini, L., Fabbroni, V., Perigli, G., Capaccioli, S., Masini, L.: The role of cyclooxy- 
genase-2 in mediating the effects of histamine on cell proliferation and vascular endothelial growth factor production in colorectal cancer. Clin Cancer Res 11, 6807-6815 (2005).

55. Theoharides, T. C., Rozniecki, J. J., Sahagian, G., Jocobson, S., Kempuraj, D., Conti, P., Kalomeromitros, D.: Impact of stress and mast cells on brain metastases. J Neuroimmunol 205, 1-7 (2008).

56. Yurt, R., Austen, K. F.: Preparative purification of the rat mast cell chymase: Characterization and interaction with granule components. J Exp Med 146, 1405-1419 (1977).

57. Schwartz, L. B., Austen, K. F.: Enzymes of mast cell granule. J Invest Dermatol 74, 349-353 (1980).

58. Welle, M.: Development, significance, and heterogeneity of mast cells with particular regard to the mast cell-specific proteases chymase and tryptase. J Leukoc Biol 61, 233 245 (1997).

59. Pejler, G., Rönnberg, E., Waern, I., Wernersson, S.: Mast cell proteases: Multifaceted regulators of inflammatory disease. Blood 115, 4981-4990 (2010).

60. Wernersson, S., Pejler, G.: Mast cell secretory granules: Armed for battle. Nature Rev Immunol 14, 478-494 (2014).

61. Ruoss, S. J., Hartmann, T., Caughey, G. H.: Mast cell tryptase is a mitogen for cultured fibroblasts. J Clin Invest 88, 493-499 (1991).

62. Fink, K., Boratynski, J.: The role of metalloproteinases in modification of extracellular matrix in invasive tumor growth, metastasis and angiogenesis. Postepy Hig Med Dosw 66, 609-628 (2012).

63. Woolley, D. E.: Collagenolytic mechanisms in tumor cell invasion. Cancer Metastasis Rev 3, 361-372 (1984).

64. Ribatti, D.: Mast cells and macrophages exert beneficial and detrimental effects on tumor progression and angiogenesis. Immunol Lett 152, 83-88 (2013).

65. Bulfone-Paus, S., Paus, R.: Osteopontin as a new player in mast cell biology. Eur J immunol 38, 338-341 (2008).

66. Oldford, S. A., Haidl, I. D., Howatt, M. A., Leiva, C. A., Johnston, B., Marshall, J. S.: A critical role for mast cells and mast cell-derived IL-6 in TRL2-mediated inhibition of tumor growth. J Immunol 185, 7067-7076 (2010).

67. Halova, I., Draberova, L., Draber, P.: Mast cell chemotaxis - Chemoattractants and signaling pathways. Front Immunol 25, 119 (2012)

68. Aoki, M., Pawankar, R., Niimi, Y., Kawana, S.: Mast cells in basal cell carcinoma express VEGF, IL-8 and Rantes. Int Arch Allergy Immunol 130, 216-223 (2003).

69. Katsanos, G. S., Anogeianaki, A., Orso, C., Teté, S., Salini, V., Antinolfi, P. L., Sabatino, G.: J Biol Regul Homeost Agents 22, 145-151 (2008).

70. Melillo, R. M., Guarino, V., Galdiero, M. R., Liotti, F., Prevete, N., Rossi, F. W., Basolo, F., Ugolini, C., de Paulis, A., Santoro, M., Marone, G.: Mast cells have a protumorigenic role in human thyroid cancer. Oncogene 29, 6203-6215 (2010).

71. Ruan, Y., Guan, Y., Wu, Z., Zhang, Z., Zheng, C.: The relationship between RANTES and mast cells recruitment in the surroundings of intrahepatic implanted tumors. Clin Lab 49, 65-69 (2003).

72. Khazaie, K., Blatner, N. R., Khan, M. W., Gounari, F., Gounaris, E., Dennis, K., Bonertz, A., Tsai, F. N., Struch, M. J., Cheon, E., Philips, J. D., Beckhove, P., Bentrem, D. J.: The significant role of mast cells in cancer. Cancer Metastasis Rev 30, 45-60 (2011). 
73. Maltby, S., Khazaie, K., McNagny, K. M.: Mast cells in tumor growth: Angiogenesis, tissue remodeling and immune modulation. Biochem Biophys Acta 1796, 19-26 (2009).

74. Boesinger, J., Tsai, M., Maurer, M., Yamaguchi, M., Brown, L. F., Claffey, K. P., Dvorak, H. E., Galli, S. J.: Mast cell can secrete vascular permeability factor/vascular endothelial growth factor and exhibit enhanced release after immunoglobulin E-dependent upregulation of Fce receptor I expression. J Exp Med 188, 1135-1145 (1998).

75. Ribatti, D., Crivellato, E.: Mast cells, angiogenesis, and tumor growth. Biochem Biophys Acta 1822, 2-8 (2012).

76. Lin, T. J., Issekutz, T. B., Marshall, J. S.: SDF1 induces IL-8 production and transendothelial migration of human cord-blood derived mast cells. In Arch Allergy Immunol 124, 142-145 (2001).

77. Trabucchi, E., Radaelli, E., Marazzi, M., Foschi, D., Musazzi, M., Veronesi, A. M., Montorsi, W.: The role of mast cells in wound healing. Int J Tissue React 10, 367-372.

78. Nienartowicz, A., Sobaniec-Lotowska, M. E., Jarocka-Cyrta, E., Lemancewicz, D.: Mast cells in neoangiogenesis. Med Sci Monit 12, RA53-RA56 (2006).

79. Folkman, J., Shing, Y.: Control of angiogenesis by heparin and other sulphated polysaccharides. Adv Exp Med Biol 313, 355-364 (1992).

80. Folkman, J., Langer, R., Linhardt, R. J., Haudenschild, C., Taylor, S.: Angiogenesis inhibition and tumor regression caused by heparin or a heparin fragment in the presence of cortisone. Science 22, 719-725 (1983).

81. Tomita, M., Matsuzaki, Y., Onitsuka, T.: Effect of mast cells on tumor angiogenesis in lung cancer. Am Thorac Surg 69, 1686-1690 (2000).

82. Grützkau, A., Krüger-Krasagakes, S., Baumeister, H., Schwarz, C., Kögel, H., Welker, P., Lippert, U., Henz, B. M., Möller, A.: Synthesis, storage and release of vascular endothelial growth factor/vascular permeability factor (VEGF/VPF) by human mast cells: Implications for the biological significance of VEGF206. Mol Biol Cell 9, 875-884 (1998).

83. Fraser, R. A., Simpson, J. G.: Role of mast cells in experimental tumour angiogenesis. Ciba Found Symp 100, 120-131 (1983).

84. Stockmann, C., Schadendorf, D., Klose, R., Helfrich, I.: The impact of immune system on tumor: Angiogenesis and vascular remodeling. Front Oncol 4, 69 (2014).

85. Marech, I., Ammendola, M., Gadaleta, C., Zizzo, N., Oakley, C., Gadaleta, C. D., Ranieri, G.: Possible biological and translational significance of mast cells density in colorectal cancer. World J Gastroenterol 20, 8910-8920 (2014).

86. Puxxeddu, I., Piliponsky, A. M., Bachelet, I., Levi-Schaffer, F.: Mast cells in allergy and beyond. Int J Biochem Cell Biol 35, 1601-1607 (2003).

87. Weller, K., Foitzik, K., Paus, R., Syska, W., Maurer, M.: Mast cells are required for normal healing of skin wounds in mice. FASEB J 20, 2366-2368 (2006).

88. Noli, C., Miolo, A.: The mast cell in wound healing. Vet Dermatol 12, 303-313 (2001).

89. Younan, G. J., Heit, Y. I., Dastouri, P., Kekhia, H., Xing, W., Gurish, M. F., Orgill, D. P.: Mast cells are required in the proliferation and remodeling phases of microdeformational wound therapy. Plast Reconstr Surg 128, 649e-658e (2011).

90. Weller, C. L., Collington, S. J., Williams, T., Lamb, J. R.: Mast cells in health and disease. Clin Sci 120, 473-484 (2011).

91. Egozi, E. I., Ferreira, A. M., Burns, A. L., Gamelli, R. L., Dipietro, L. A.: Mast cells modulate the inflammatory but not the proliferative response in healing wounds. Wound Repair Regen 11, 46-54 (2003). 
92. Wuff, B. C., Parent, A. E., Meleski, M. A., DiPietro, L. A., Schrementi, M. E., Wilgus, T. A.: Mast cells contribute to scar formation during fetal wound healing. J Invest Dermatol 132, 458-465 (2012).

93. Oskeritzian, C. A.: Mast cells and wound healing. Adv Wound Care 1, $23-28$ (2012).

94. Kennelly, R., Conneely, J. B., Bouchier-Hayes D., Winter, D. C.: Mast cells in tissue healing: From skin to the gastrointestinal tract. Curr Pharm Des 17, 3772-3775 (2011).

95. Artuc, M., Hermes, B., Steckelings, U. M., Grützkau, A., Henz, B. M.: Mast cells and their mediators in cutaneous wound healing - Active participants or innocent bystanders? Exp Dermatol 9, 1-16 (1999).

96. Lunderius-Andersson, C., Enoksson, M., Nilsson, G.: Mast cells respond to cell injury through the recognition of IL-33. Front Immunol 3, 82 (2012).

97. Douaiher, J., Succar, J., Lancerotto, L., Gurish, M. F., Orgill, D. P., Hamilton, M. J., Krilis, S. A., Stevens, R. L.: Development of mast cells and importance of their tryptase and chymase serine proteases in inflammation and wound healing. Adv Immunol 122, 211-252 (2014).

98. Csaba, G.: The immune endocrine system. A new endocrine theory: The problem of the packed transport. Orv Hetil 152, 777-784 (2011).

99. Abdel-Majid, R. M., Marshall, J. S.: Prostaglandin E2 induces degranulation-independent production of vascular endothelial growth factor by human mast cells. J Immunol 172, 1227-1236 (2004).

100. Csaba, G., Kovács, P.: Hormones in the nucleus of mast cells: Confocal microscopic immunocytochemical observations. Horm Metab Res 41, 621-625 (2009).

101. Csaba, G., Pállinger, É.: Gender dependence in the hormone content of the immune cells. Acta Physiol Hung 96, 45-50 (2009).

102. Csaba, G., Kovács, P., Pállinger, É.: Effect of a single neonatal endorphin treatment on the hormone content of adult rat white blood cells and mast cells. Cell Biol Int 27, 423427 (2003).

103. Csaba, G., Kovács, P., Pállinger, É.: Immunologically demonstrable hormones and hormone-like molecules in rat white blood cells and mast cells. Cell Biol Int 28, 487-490 (2004).

104. Kempuraj, D., Papadopoulou, N. G., Lytinas, M., Huang, M., Kandere-Grzybowska, K., Madhappan, B., Boucher, W., Christodoulou, S., Athanassiou, A., Theoharides, T. C.: Corticotropin-releasing hormone and its structurally related urocortin are synthesized and secreted by human mast cells. Endocrinology 145, 43-48 (2004).

105. Martynova, M. G., Bystrova, O. A., Moiseeva, O. M., Evdorin, A. L., Kondratov, K. A., Medvedeva, N. D.: The presence of ANP in rat peritoneal mast cells. Cell Res 15, 811816 (2005).

106. Tanaka, A., Nomura, Y., Matsuda, A., Ohmori, K., Matsuda, H.: Mast cells function as an alternative modulator of adipogenesis through 15-deoxy-delta-12, 14-prostaglandin $\mathrm{J}_{2}$. Am J Physiol Cell Physiol 301, C1360-C1367 (2011).

107. Anand, P., Singh, B., Jaggi, A. S., Singh, N.: Mast cells: An expanding pathophysiological role from allergy to other disorders. Naunyn Schmiedebergs Arch Pharmacol 385, 657-670 (2012).

108. Maldonado, M. D., Mora-Santos, M., Naji, L., Carrascosa-Salmoral, M. P., Naranjo, M. C., Calvo, J. R.: Evidence of melatonin synthesis and release by mast cells. Possible modulatory role on inflammation. Pharmacol Res 62, 282-287 (2010). 
109. Csaba, G., Kovács, P., Pállinger, É.: Hormones in the nucleus: Immunologically demonstrable biogenic amines (serotonin, histamine) in the nucleus of rat peritoneal mast cells. Life Sci 78, 1871-1877 (2006).

110. Nakazawa, S., Sakanaka, M., Furuta, K., Natsuhara, M., Takano, H., Tsuchiya, S., Okuno, Y., Ohtsu, H., Nishibori, M., Thurmond, R. L., Hirasawa, N., Nakayama, K., Ichikawa, A., Sugimoto, Y., Tanaka, S.: Histamine synthesis is required for granule maturation in murine mast cells. Eur J Immunol 44, 204-214 (2014).

111. Ohtsu, H., Tanaka, S., Terui, T., Hori, Y., Makabe-Kobayashi, Y., Pejler, G., Tchougounova, E., Hellman L., Gertsenstein, M., Hirasawa, N., Sakurai, E., Buzás, E., Kovács, P., Csaba, G., Kittel, A., Okada, M., Hara, M., Mar, L., Numayama-Tsuruta, K., IshigakiSuzuki, S., Ohuchi, K., Ichikawa, A., Falus, A., Watanabe, T., Nagy, A.: Mice lacking histidine decarboxylase exhibit abnormal mast cells. FEBS Lett 502, 53-56 (2001).

112. Csaba, G., Kovács, P., Buzás, E., Mazán, M., Pállinger, É.: Histidine decarboxylase (HDC) knock out mouse immune cells have altered expression of ACTH, triiodothyronine and endorphin. Inflamm Res 56, 428-431 (2007).

113. Iwamura, T., Shimizu, K., Tanaka, S.: Morphological and histochemical characteristics of mast cells and the content of in-tissue histamin in various pathological parathyroids: Do mast cells participate in hormone secretion in human parathyroids? J Nippon Med Sch 69, 347-354 (2002).

114. Csaba, G.: Immunoendocrinology: Faulty hormonal imprinting in the immune system. Acta Microbiol Immunol Hung 61, 89-106 (2014).

115. Csaba, G., Kovács, P., Pállinger, É.: Effect of endorphin exposure at weaning on the endorphin and serotonin content of white blood cells and mast cells in adult rat. Cell Biochem Funct 22, 197-200 (2004).

116. Csaba, G., Pállinger, É.: Thyrotropic hormone (TSH) regulation of triiodothyronine (T3) concentration in immune cells. Inflamm Res 58, 151-154 (2009).

117. Siebler, T., Robson, H., Bromley, M., Stevens, D. A., Shalet, S. M., Williams, G. R.: Thyroid status affects number and localization of thyroid hormone receptor expressing mast cells in bone marrow. Bone 30, 259-266 (2002).

118. Catini, C., Legnaioli, M.: Role of mast cells in health: Daily rhytmic variations in their number, exocytotic activity, histamine and serotonin content in the rat thyroid gland. Eur J Histochem 36, 501-516 (1992).

119. Csaba, G., Dunay, C., Fischer, J., Bodoky, M.: Hormonal relationships of mastocytogenesis in lymphatic organs. 3. Effect of pineal body-thyroid-thymus system on mast cell production. Acta Anat 71, 565-580 (1968).

120. Csaba, G., Bodoky, M., Törö, I.: Hormonal relationships of mastocytogenesis in lymphatic organs. II. Effect of epiphysectomy on the genesis of mast cells. Acta Anat 61, 289-296 (1965).

121. Csaba, G., Baráth, P.: Effect of pinealectomy on the 3 H-5HT uptake of mast cells in the thyroid gland of the rat. Acta Anat 89, 442-451 (1974).

122. Maslinska, D., Laure-Kamionowska, D., Deregowski, K., Maslinski, S.: Association of mast cells with calcification in the human pineal gland. Folia Neuropathol 48, 276-282 (2010).

123. Krishnaswamy, G., Kelley, J., Johnson, D., Youngberg, G., Stone, W., Huang, S. K., Bieber, J., Chi, D. S.: The human mast cell: Functions in physiology and disease. Front Biosci 6, 1109-1127 (2001). 
124. Yoshikawa, H., Tasaka, K.: Suppression of mast cell activation by glucocorticoid. Arch Immunol Ther Exp 48, 487-495 (2000).

125. Diaz, B., Barreto, E., Cordeiro, R., Perretti, M., Martins, M., Silva, P.: Enhanced serum glucocorticoid levels mediate the reduction of serosal mast cell numbers in diabetic rats. Life Sci 68, 2925-2932 (2001).

126. Csaba, G., Dunay, C., Oláh, I., Törő, I.: Effect of glucocorticoids on the thymus. I. Histochemical and electronmicroscopic investigation of mast cell formation. Acta Biol Acad Sci Hung 18, 345-361 (1967).

127. Csaba, G., Kiss, J., Dunay, C.: Elective localization of 3H-corticosterone in mast cells. Experientia 15, 267-269 (1967).

128. Csaba, G., Oláh, I., Kiss, J., Dunay, C.: The localization of 3H-corticosterone in mast cell granules by electron microscopic autoradiography. Experientia 23, 944 (1967).

129. Chen, W., Beck, I., Schober, W., Brockow, K., Effner, R., Buters, J. T., Behrendt, H., Ring, J.: Human mast cells express androgen receptors but treatment with testosterone exerts no influence on IgE-indpendent mast cell degranulation elicited by neuromuscular blocking agents. Exp Dermatol 19, 302-304 (2010).

130. Vlagoftis, H., Dimitriadou, V., Theoharides, T. C.: Progesterone triggers selective mast cell secretion of 5-hydroxytryptamine. Int Arch Allergy Appl Immunol 93, 113-119 (1990).

131. Zhao, X. J., McKerr, G., Dong, Z., Higgins, C. A., Carson, J., Yang, Z. Q., Hannigan, B. M.: Expression of oestrogen and progesterone receptors by mast cells alone, but not lymphocytes, macrophages or other immune cells in human upper airways. Thorax $\mathbf{5 6}$, 205-211 (2001).

132. Jensen, F., Woudwyk, M., Teles, A., Woidacki, K., Taran, F., Costa, S., Malfertheiner, S. F., Zenclussen, A. C.: Estradiol and progesterone regulate the migration of mast cells from the periphery to the uterus and induce their maturation and degranulation. PLoS One 5, e14409 (2010).

133. Zierau, O., Zenclussen, A. C., Jensen, F.: Role of female sex hormones, estradiol and progesterone, in mast cell behavior. Front Immunol 3, 169 (2012).

134. Vasiadi, M., Kempuraj, D., Boucher, W., Kalogeromitros, D., Theoharides, T. C.: Progesterone inhibits mast cell secretion. Int J Immunopathol Pharmacol 19, 787-794 (2006).

135. Susko, I., Mornjakovic, Z.: Effect of pinealectomy on mastocyte count in the thymus of the rat. Med Arh 57, 7-8 (2003).

136. Calvo, J. R., Gonzalez-Janes, C., Maldonado, M. D.: The role of melatonin in the cells of the innate immunity: A review. J Pineal Res 55, 103-120 (2013).

137. Cao, J., Papadopoulou, N., Kempuraj, D., Boucher, W. S., Sugimoto, K., Cetrulo, C. L., Theoharides, T. C.: Human mast cells express corticotropin-releasing hormone (CRH) receptors and $\mathrm{CRH}$ leads to selective secretion of vascular endothelial growth factor. J Immunol 174, 7665-7675 (2005).

138. Jaiswal, K., Krishna, A.: Effects f hormones on the number, distribution and degranulation of mast cells in the ovarian complex of mice. Acta Physiol Hung 84, 183-190 (1996).

139. Irman-Florianc, T., Erjavec, F.: The effect of adrenocorticotropin on histamine and 5-hydroxytriptamine secretion from rat mast cells. Agents Actions 14, 454-457 (1984).

140. Rasanen, T.: Different hormonal responses of mast cells in gastric mucosa and dermis in the rat. Scand J Gastroenterol 2, 118-123 (1967). 
141. Tsakalos, N. D., Theoharides, T. C., Kops, S. K., Askenase, P. W.: Induction of mast cell secretion by parathormone. Biochem Pharmacol 32, 355-360 (1983).

142. Chiapetta, N., Gruber, B.: The role of mast cells in osteoporosis. Semin Arthritis Rheum 36, 32-36 (2006).

143. Turner, R. T., Iwaniec, U. T., Marley, K., Sibonga, J. D.: The role of mast cells in parathyroid bone disease. J Bone Miner Res 25, 1637-1649 (2010).

144. Cavalcher-Macado, S. C., de Lima, W. T., Damazo, A. S., de Frias Carvalho, V., Martins, M. A., e Silva, P. M., Sannomiya, P.: Down-regulation of mast cell activation and airway reactivity in diabetic rats: role of insulin. Eur Respir 24, 552-558 (2004).

145. Zhang, J., Shi, G. P.: Mast cells and metabolic syndrome. Biochem Biophys Acta, 1822, 14-20 (2012).

146. Harvima, I. T., Nilsson, G.: Stress, the neuroendocrine system and mast cells: Current understanding of their role in psoriasis. Expert Rev Clin Immunol 8, 236-241 (2012).

147. Csaba, G., Tekes, K., Pállinger, É.: Influence of perinatal stress on the hormone content in immune cells of adult rats: Dominance of ACTH. Horm Metab Res 41, 617-620 (2009).

148. Kumar, V., Sharma, A.: Mast cells: Emerging sentinel innate immune cells with diverse role in immunity. Mol Immunol 48, 14-25 (2010).

149. Matsuguchi, T.: Mast cells as critical effectors of host immune defense against Gramnegative bacteria. Curr Med Chem 19, 1432-1442 (2012).

150. Purcell, W. M., Hanahoe, T. H.: A novel source of mast cells: The human placenta. Agents Actions 33, 8-12 (1991).

151. Garfield, R. E., Irani, A. M., Schwartz, L. B., Bytautiene, E., Romero, R.: Structural and functional comparison of mast cells in the pregnant versus nonpregnant human uterus. Am J Obstet Gynecol 194, 261-267 (2006).

152. Bytautiene, E., Vedernikov, Y. P., Saade, G. R., Romero, G., Garfield, R. E.: Endogeneus mast cell degranulation modulates cervical contractility in the guinea pig. Am J Obstet Gynecol 186, 438-445 (2002).

153. Rudolph, M. I., Reinicke, K., Cruz, M. A., Gallardo, V., Gonzalez, C., Bardisa, L.: Distribution of mast cells and the effect of their mediators on contractility in human myometrium. Br J Obstet Gynecol 100, 1125-1130 (1993).

154. Bytautiene, E., Vedernikov, Y. P., Saade, G. R., Romero, R., Garfield, R. E.: Degranulation of uterine mast cells modifies contractility of isolated myometrium from pregnant women. Am J Obstet Gynecol 191, 1705-1710 (2004).

155. Szelag, A., Merwid-Lad, A., Trocha, M.: Histamine receptors in the female reproductive system. Part I. Role of the mast cells and histamine in female reproductive system. Ginekol Pol 73, 627-635 (2002).

156. Szelag, A., Merwid-Lad, A., Trocha, M.: Histamine receptors in the female reproductive system. Part II. The role of histamine in the placenta, histamine receptors and the uterus contractility. Ginekol Pol 73, 636-644 (2002).

157. Marx, L., Arck, P., Kieslich, C., Mittelrechner S., Kapp, M., Dietl, J.: Decidual mast cells might be involved in the onset of human first-trimester abortion. Am J Reprod Immunol 41, 34-40 (1999).

158. Cocchiara, R., Lampiasi, N., Albeggiani, G., Azzolina, A., Bongiovanni, A., Gianaroli, L., Di Blasi, F., Geraci, D.: A factor secreted by human embryo stimulates cytokine release by uterine mast cells. Mol Hum Reprod 2, 781-791 (1996). 
159. Woidacki, K., Jensen, F., Zenclussen, A. C.: Mast cells as novel mediators of reproductive processes. Front Immunol 14, 29 (2013).

160. Varayoud, J., Ramos, J. G., Bosquiazzo, V. L., Munoz-de-Toro, M., Luque, E. H.: Mast cells degranulation affects angiogenesis in the rat uterine cervix during pregnancy. Reproduction 127, 379-387 (2004).

161. Poglio, S., De Toni-Costes, F., Arnaud, E., Laharrague, P., Espinosa, E., Casteilla, L., Cousin, B.: Adipose tissue as a dedicated reservoir of functional mast cell progenitors. Stem Cells 28, 2065-2072 (2010).

162. Ishijamaa, Y., Ohmori, S., Ohneda, K.: Mast cell deficiency results in the accumulation of preadipocytes in adipose tissue in both obese and non-obese mice. FEBS Open Bio 28, 18-24 (2013).

163. Altintas, M. M., Nayer, B., Walford, E. C., Johnson, K. B., Gaidosh, G., Reiser, J., De la Cruz-Munoz, N., Ortega, L. M., Nayer, A.: Leptin deficiency-induced obesity affects the density of mast cells in abdominal fat depots and lymph nodes in mice. Lipids Health Dis 11, 21 (2012).

164. Shi, M. A., Shi, G. P.: Different roles of mast cells in obesity and diabetes: Lessons from experimental animals and humans. Front Immunol 25, 3-7 (2012).

165. Sismanopoulos, N., Delivanis, D. A., Marommati, D., Hatziagelaki, E., Conti, P., Theoharides, T. C.: Do mast cells link obesity and asthma? Allergy 68, 8-15 (2013).

166. Marone, G., Casolaro, V., Patella, V., Florio, G., Triggiani, M.: Molecular and cellular biology of mast cells. Int Arch Allergy Immunol 114, 207-217 (1997).

167. Roedewald, H. R., Feyerabend, T. B.: Widespread immunological functions of mast cells: Fact or fiction? Immunity 37, 13-24 (2012).

168. He, A., Shi, G. P.: Mast cell chymase and tryptase as targets for cardiovascular and metabolic diseases. Curr Pharm Des 19, 1114-1125 (2013).

169. Xu, J. M., Shi, G. P.: Emerging role of mast cells and macrophages in cardiovascular and metabolic diseases. Endocr Rev 33, 71-108 (2012).

170. Bot, I., Shi, G. P., Kovanen, P. T.: Mast cells as effectors in atherosclerosis. Arterioscler Thromb Vasc Biol 35, 265-271 (2015).

171. Nelson, R. B., Siman, R., Iqbal, M. A., Potter, H.: Identification of chymotrypsin-like mast cell protease in rat brain capable of generating the N-terminus of the Alzheimer amyloid beta-protein. J. Neurochem 61, 567-577 (1993).

172. Hodges, K., Kennedy, L., Meng, F., Alpini, G., Francis, H.: Mast cells, disease and gastrointestinal cancer: A comprehensive review of recent findings. Transl Gastrointest Cancer 1, 138-150 (2012).

173. Van Nassauw, L., Adriaensen, D., Timmermans, J. P.: The bidirectional communication between neurons and mast cells within the gastrointestinal tract. Auton Neurosci 133, 91-103 (2007).

174. Tore, F., Tuncel, N.: Mast cells: Target and source of neuropeptides. Curr Pharm Des 15, 3433-3445 (2009).

175. Csaba, G.: Hormones in the immune system and their possible role. A critical review. Acta Microbiol immunol Hung 61, 241-260 (2014).

176. Puzianowska-Kuznicka, M., Pietrzak, M., Turowska, O., Nauman, A.: Thyroid hormones and their receptors in the regulation of cell proliferation. Acta Biochem Pol 53, 641-650 (2006).

177. Dentice, M., Ambrosio, R., Salvatore, D.: Role of type 3 deiodinase in cancer. Expert Opin Ther Targets 13, 1363-1373 (2009). 
178. Csaba, G.: The hormonal system of the unicellular Tetrahymena: A review with evolutionary aspects. Acta Microbiol Immmmunol Hung 59, 131-156 (2012).

179. Csaba, G.: The unicellular Tetrahymena as a model cell for receptor research. Int Rev Cytol 95, 327-377 (1985).

180. Csaba, G.: Hormonal imprinting in the unicellular Tetrahymena: The proto-model of epigenetics. Acta Microbiol Immunol Hung 59, 291-310 (2012).

181. von Dorsche, H.H., Fehrmann, P., Sulzmann, R.: Die Mastzelle als einzellige endokrine Drüse. Acta Anat 77, 560-569 (1970).

182. Cavalcante, M. C., de Andrade, L. R., Du Bocage Santos-Pinto, C., Straus, A. H., Takahashi, H. K., Allodi, S., Pavao, M. S.: Colocalization of heparin and histamine in the inracellular granules of test cells from the invertebrate Styela plicata (Chordata-Tunicata). J Struct Biol 137, 313-321 (2002).

183. Wong, G. W., Zhuo, L., Kimata, K., Lam, B. K., Satoh, N., Stevens, R. L.: Ancient origin of mast cells. Biochim Biophys Res Com 451, 314-318 (2014).

184. Csaba, G., Kovács, P.: Perinuclear localization of biogenic amines (serotonin and histamine) in rat immune cells. Cell Biol Int 30, 861-865 (2006).

185. Kitamura, Y., Oboki, K., Ito, A.: Development of mast cells. Proc Jpn Acad Ser B Phys Biol Sci 83, 164-174 (2007).

186. Csaba, G., Hodinka, L.: The thymus as a source of mast cells in the blood. Acta Biol Acad Sci Hung 21, 333-334 (1970).

187. Csaba, G., Törö, I., Bodoky, M.: On the formation of mast cells in the thymus and lymphatic organs. Z Mikr Anat Forsch 70, 242-251 (1963).

188. Csaba, G., Hodinka, L., Surján, L. jr.: Transport of mast cells by the blood circulation. Experientia 25, 735-736 (263).

189. Csaba, G., Hodinka, L., Bozsóky, S., Farkas, K.: Tissue mast cells in human blood. Preliminary report. Haematologia 4, 415-417 (1970).

190. Csaba, G., Török, O.: Physiology of mast cells. IV. Role of blood transport in the tansformation of mast cells. Acta Biol Acad Sci Hung 23, 369-376 (1972).

191. Kambe, N., Hiramatsu, H., Shimonaka, M., Fujino, H., Nishikomori, R., Heike, T., Ueyama, Y., Matsuyoshi, N., Miyachi, Y., Nakahata, T.: Development of both human connective tissue-type and mucosal-type mast cells in mice from hemopoietic stem cells with identical distribution pattern to human body. Blood 103, 860-867 (2004).

192. Csaba, G., Török, O.: Physiology of mast cells. I. Behavior of mast cells in tissue culture. Acta Biol Acad Sci Hung 21, 63-744 (1970).

193. Csaba, G.: Mechanism of the formation of mast cell granules. VII. Participation of amines and basic proteins in the formation of mast cell granule. Analysis of the heterogeneity of mast cells. Acta Biol Acad Sci Hung 22, 155-168 (1971).

194. Csaba, G., Baráth, P.: Heterogeneity of mast cell populations as emerging from studies with labelled amines and amine precursors. Acta Biol Acad Sci Hung 25, 323-325 (1974).

195. Csaba, G.: Mechanism of the formation of mast cell granules. 3. Self-regulating system of granule formation. Acta Biol Acad Sci Hung 20, 211-218 (1969).

196. Csaba, G.: Mechanism of the formation of mast cell granules. II. Cell-free model. Acta Biol Acad Sci Hung 20, 205-210 (1969).

197. Csaba, G., Surján, L. jr.: Demonstration of histones in the granules of developing mast cells induced by biogenic amine. Acta Biol Acad Sci Hung 21, 243-245 (1970). 
198. Csaba, G., Surján, L. jr.: Mechanism of the formation of mast cell granules. V. Histochemical detection of histones in the mast cell granules. Acta Biol Acad Sci Hung 21, 341-346 (1970).

199. Csaba, G., Kapa, E.: Uptake of heparin by cells. Nature 187, 711-713 (1960).

200. Csaba, G.: Regulation of Mast Cell Formation. Academic Press, Budapest, 1972.

201. Rigoni, A., Colombo, M. P., Pucillo, C.: The role of mast cells in molding the tumor microenvironment. Cancer Microenviron (2014), Epub ahead of print.

202. Papadimitriou, E., Polykratis, A., Hatziapostolou, M., Parthymou, A., Polytarchou, C., Mikelias, C.: Heparin affin regulatory peptide: A new target for tumor therapy? Curr Cancer Drug Targets 4, 471-482 (2004).

203. Groot Kormelink, T., Abudukelimu, A., Redegeld, F. A.: Mast cells as target in cancer therapy. Curr Pharm Des 15, 1868-1878 (2009).

204. Csaba, G., Ács, T., Horváth, C., Kapa, E.: Some new data concerning the biology of tumours. Br J Cancer 15, 367-375 (1961).

205. Csaba, G., Körösi, J.: A new antitumor agent: Phenazathionium-mustard salt. Neoplasma 15, 443-445 (1968).

206. Csaba, G., Kiss, J., Kőrösi, J.: Intratumoral localization of phenazathionium-mustard chloride: A new antitumor agent. Neoplasma 16, 145-149 (1969).

207. Csaba, G., Mold, K., Körösi, J.: On the effect of tumor-inhibiting agents bound to inactivated heparin on tissue cultures. Neoplasma 11, 345-351 (1964).

208. Csaba, G., Kőrösi, J., Horváth, C., Mold, K., Ács, T.: Effect of heparin-bound alkylating agents and enzyme inhibitors on neoplastic growth. Neoplasma 11, 137-144 (1964).

209. Németh, L.: Experimental studies on the tumour inhibitory effect of heparin-degranol (Zitofenton). Neoplasma 16, 137-143 (1969).

210. Sellei, C.: Chemotherapy of Neoplastic Diseases. Academic Press, Budapest, 1970. 